\title{
Performance of Garden Pea (Pisum sativum var hortense L.) Varieties under Conventional and Organic Nutrient Sources under Sub-Himalayan Foot Hills of West Bengal, India
}

\author{
S. Vijay Kumar, Suchand Datta* and Shibnath Basfore \\ Department of Vegetable and Spice Crops, Uttar Banga Krishi Viswavidyalaya, Pundibari, \\ Cooch Behar, WB-736165, India \\ *Corresponding author
}

\begin{tabular}{|l|}
\hline Ke y w o r d s \\
Conventional, \\
Garden pea, \\
Organic, Quality, \\
yield
\end{tabular}

\section{Introduction}

Garden pea (Pisum sativum var. hortense L.) is one of the important cool season vegetable crop belongs to family leguminosae, grown all over the world for fresh and processed forms. It is originated in the near East and
An experiment was conducted during 2014-15 and 2015-16 at the Instructional Farm of Uttar Banga Krishi Vishwavidyalaya, Pundibari, Cooch Behar, West Bengal to study the performance of garden pea (Pisum sativum var hortense L.) varieties under conventional and organic nutrient sources. The experiment was laid out in factorial randomized block design with 3 three replications. Two growing conditions (conventional and organic) and seven garden pea varieties (namely, KSP-110, Arkel, Super Gold -10, PSM-3, Azad P-1, Monsson-10 and Kohinoor-10) were taken as treatment. Irrespective of treatments seeds were inoculated with Rhizobium leguminosarum $(20 \mathrm{gm} / \mathrm{kg}$ of seed). In the conventional condition, recommended dose of fertilizer of $\mathrm{N}: \mathrm{P}_{2} \mathrm{O}_{5}: \mathrm{K}_{2} \mathrm{O}(30: 50: 50 \mathrm{~kg} / \mathrm{ha})$ and FYM (15t/ha) was applied as nutrient source whereas, in organic condition the nutrient source was vermicompost@ 2 t/ha + Rock phosphate@106 kg/ha + Wood ash@1.17 t/ha + FYM (15t/ha). Higher yield was recorded in conventional sources of nutrients as compared to organic sources of nutrients. However, higher magnitude of quality parameters viz, protein $\%$, beta carotene and ascorbic acid content was recorded in organic sources of nutrients. Under conventional sources of nutrients, KSP-110 recorded significantly higher yield of $13.03 \mathrm{t} / \mathrm{ha}$ followed by Kohinoor-10 (12.03 t/ha) and Monsoon-10 (10.15 t/ha). In organic sources of nutrients, the higher yield was recorded in Kohinoor-10 (11.48 t/ha) which was also statistically at par with KSP-110 (11.27 t/ha). Considering the fresh pod yield and benefit: cost ratio, the garden pea variety KSP-110 may be selected for growing under conventional nutrient sources whereas, Kohinoor -10 may be selected for growing with organic sources of nutrients under the terai zone of West Bengal. 
production of 1.3 lakh MT. But productivity of the crop is low (6.1 MT/ha) as compared to national productivity (Anonymous, 2014). It is grown as a vegetable crop for its fresh and dried seed. It is being recognized as an important protein supplement. It contains good amount of protein, along with carbohydrates, sugars, minerals, Vitamin A, Vitamin B and Vitamin $\mathrm{C}$ and essential amino acids. Apart from these, large proportion of peas are processed (canned, frozen or dehydrated) for consumption in off season. Being a leguminous crop, it enriches the soil by fixing atmospheric nitrogen in the soil and also provides an effective cover to the land thus restricts soil erosion. Its cultivation maintains soil fertility through biological nitrogen fixation in association with symbiotic Rhizobium prevalent in its root nodules and plays a vital role in fostering sustainable agriculture. Therefore, apart from meeting its own requirement of nitrogen, peas are wellknown to leave behind residual nitrogen of about $50-60 \mathrm{~kg} / \mathrm{ha}$ in the soil (Negi et al., 2006). Garden pea has a high demand in India. Hence, high demand of pea can only be meet up by increasing its productivity. This can be done by many ways of which the most important are the introduction of high yielding varieties and choice of right types of varieties for growing under both organic and conventional farming conditions is of utmost importance as all the recommended/released varieties in present scenario have been developed and evaluated. It has been often observed that the high input responsive varieties fail to perform better under low input organic farming conditions.

Modern agriculture is getting more and more dependent upon the supply of synthetic inputs such as chemical fertilizers, pesticides and herbicides etc. which are inevitable to meet high food demand for growing population in the world. However, excessive, imprudent and imbalanced use of these inputs may throw devastating impacts on the water, air and soil environments. Probably the soil environment is the most vulnerable to the direct effects of these practices in modern agriculture. They could destroy the soil fertility in a long run which compels the scientific community to look for the alternatives like organic farming (Mishra, 2014). In case of garden pea, plant can readily absorb and utilize the nutrients and express the highest value in all vegetative as well as productive characters under combined application of organics and in organics.

Organic farming is an alternative to conventional agriculture for sustainable food and fibre production with high consumer demand. Proponents of organic farming argue that it is a sustainable alternative to conventional farming, providing crops with high export demand and lower environmental impact (Wood et al., 2006). So, there is an urgent need to identify the potential genotypes/varieties responsive to low input conditions of both organic and conventional farming conditions. Hence, the present study was designed to evaluate performance of garden pea varieties with the application of conventional and organic nutrient sources.

\section{Materials and Methods}

The field experiment for present investigation was carried out during rabi season of 2014-15 and 2015-16 at Instructional Farm of the Faculty of Horticulture, Uttar Banga Krishi Viswavidyalaya, Pundibari, Cooch Behar, West Bengal, India. The area lies under the Terai agro climatic zone of West Bengal which is characterized by high rainfall (above $3000 \mathrm{~mm}$ annually), high relative humidity, moderate temperature, prolonged winter with high residual soil moisture. The topography of the land where experiment conducted was medium to high in situation. The soil was sandy loam in nature, coarse in texture, poor in water holding capacity with low $\mathrm{pH}$ (5.8). 
The experiment was laid out in Factorial randomized block design with 3 three replications. Two growing conditions (conventional and organic) and seven garden pea varieties (namely, KSP-110, Arkel, Super Gold -10, PSM-3, Azad P-1, Monsson-10 and Kohinoor-10) were taken as treatment. Irrespective of treatments seeds were inoculated with Rhizobium leguminosarum $(20 \mathrm{gm} / \mathrm{kg}$ of seed). In the conventional condition, recommended dose of fertilizer of $\mathrm{N}: \mathrm{P}_{2} 0_{5}: \mathrm{K}_{2} \mathrm{O}$ (30:50:50 kg/ha) and FYM (15t/ha) was applied as nutrient source whereas, in organic condition the nutrient source was vermicompost @ 2 t/ha + Rock phosphate@106 kg/ha + Wood ash @ 1.17 t/ha + FYM (15t/ha).

Five plants were selected randomly to record growth parameters like plant height, nodule characters like number of nodules per plant, nodule dry weight and yield attributing characters like, pod length, number of pods per plant, seed per pod, pod yield / plant and yield (t/ha). Quality parameters included Protein content, Ascorbic acid content, Beta carotene and shelling percentage along with benefit cost ratio. The mean data were analysed as per statistical method suggested by Gomez and Gomez (1984) with 5\% level of significance.

\section{Results and Discussion}

\section{Growth parameters}

The observation recorded on plant height of garden pea varieties as influenced by both conventional and organic nutrient sources for pooled analysis has been presented in Table 1 . It was evident that there was a significant variation in plant height with respect to different growing conditions. On the basis of pooled analysis, the higher plant height $(45.61 \mathrm{~cm})$ was recorded in conventional nutrient sources and lower in $(44.18 \mathrm{~cm})$ in organic nutrient sources. Increase in plant growth might also be due to hastened meristematic activities, better root growth and better absorption of nutrients (Singh et al., 1980) under conventional nutrient sources in the early stage of the life cycle. Among the different varieties, significantly the highest plant height was recorded in Azad P1 $(50.35 \mathrm{~cm})$ followed by Kohinoor-10 (48.08 $\mathrm{cm})$ and Monsoon-10 $(47.57 \mathrm{~cm})$ and lowest $(38.40 \mathrm{~cm})$ in Arkel. Kumar et al., (2008) reported that plant height of garden pea varieties varied from $58.33 \mathrm{~cm}$ to $88.0 \mathrm{~cm}$ under Solan conditions. Considering the interaction effect, the highest plant height was recorded in Azad P1 $(51.40 \mathrm{~cm})$ when grown with the application of conventional nutrient sources followed by Azad P1 $(49.30 \mathrm{~cm})$ when grown with organic nutrient sources followed by Monsoon-10 $(48.77 \mathrm{~cm})$ when grown with conventional nutrient sources and Kohinoor$10(48.63 \mathrm{~cm})$ when grown with conventional nutrient sources.

\section{Nodulation}

The observation recorded on number of nodules per plant of garden pea was influenced by the factors viz. growing condition, variety and their interaction. Variation in number of nodules per plant was recorded in the growing condition of the garden pea. Maximum (13.79) number of nodules per plant was recorded with the application of conventional source of nutrients and minimum (12.49) was observed in conventional source of nutrients. Orr et al., (2012) reported that the differences in microbial counts in conventional and organic condition were mainly attributed to the increased organic $\mathrm{C}$ added as manure, lower background levels of readily available nitrogen and $\mathrm{pH}$ values that are on average closer to neutral in organically managed soils. As nitrogen fixation is energy-expensive, it is reliant on carbon sources that are more 
abundant and are retained longer in organically managed compared to conventional soils. Therefore, organic soils are more likely to offer optimal conditions for nitrogen fixation and it is perhaps unsurprising that increases in soil organic carbon have been shown to stimulate nitrogen fixation, although results have been inconsistent. Considering the different varieties of garden pea, significantly the highest number of nodules per plant was recorded in Azad P1 (16.52/plant) followed by Super Gold -10(14.40/plant) and Arkel (12.98/plant) and minimum number of nodules was recorded in PSM-3 (11.02/plant). Considering the interaction effect, highest number of nodules was recorded in Azad P1 (17.07/plant) when grown with the application of organic source of nutrients followed by Azad P1 (15.97/plant) when grown with the application of conventional source of nutrients followed by Super Gold -10(15.20/plant) when grown with the application of organic source of nutrients and significantly lowest number of nodules per plant was recorded in PSM-3 (10.33/plant) when grown with the application of conventional source of nutrients.

\section{Pod character}

It was cleared that there was a minimum variation in pod length of varieties of garden pea with respect to growing condition. However, the longer pod length $(8.14 \mathrm{~cm})$ was recorded with the application of conventional source of nutrients and minimum $(8.09 \mathrm{~cm})$ with the application of organic source of nutrients. The present experiment showed that among the different varieties significantly highest pod length was recorded in Kohinoor$10(8.52 \mathrm{~cm})$. Higher pod length was recorded in Kohinoor-10 $(8.52 \mathrm{~cm})$ which was also statistically at par with Azad P1 $(8.41 \mathrm{~cm})$ and lowest pod length was recorded in Arkel $(6.72 \mathrm{~cm})$. Khichi et al., (2016) reported that the PB-89 exhibited maximum pod length
$(10.4 \mathrm{~cm})$ followed by Arka Kartik $(9.1 \mathrm{~cm})$ that was statistically at par with PB-89. Khichi et al., (2016) reported that all the cultivars PB-89 (16.43) produced maximum number of pods per plant. The cultivar Palam Priya (10.33) and JawaharMatar-2 (9.83) produced minimum number of green pods/plant. Yield is a complex character determined by the interaction of many heritable characters with soil, climate and agronomic conditions (Makasheva, 1983). Maximum yield requires maximum vegetative growth during crop establishment (Muehlbauer and McPhee, 1997). Considering the interaction effect, highest number of pods per plant was recorded in KSP-110 (20.43) when grown with the application of conventional sources of nutrient followed by KSP-110 (18.80) when grown with organic sources of nutrient followed by Kohinoor-10 (18.16) when grown with the application of conventional sources of nutrient and significantly lowest number of pods per plant was recorded in Super Gold -10(11.44) when grown by using organic sources of nutrient. Amjad et al., (2002) also reported the variation in the number of seed per pod with respect to different cultivars under Faisalbad conditions. Makasheva (1983) also reported that the number of seeds in a pod was variable depending upon the cultivar.

\section{Pod yield}

The results on fresh pod yield per plant (g/plant) and yield per ha (t/ha) revealed that there was significant difference among the growing condition, varieties and their interaction. With respect to growing condition, on the basis of pooled value the higher fresh pod yield (59.33 g/plant and $10.06 \mathrm{t} / \mathrm{ha})$ was recorded with the application of conventional sources of nutrients and lowest (54.09 g/plant and $9.17 \mathrm{t} / \mathrm{ha}$ ) fresh pod yield was recorded with the application of organic sources of nutrients. In this experiment, with respect to 
the different varieties of garden pea fresh pod yield varied from 39.82 to $75.22 \mathrm{~g} /$ plant and 7.20 to $12.15 \mathrm{t} / \mathrm{ha}$. Significantly the highest fresh pod yield was recorded in KSP-110 $(75.22 \mathrm{~g} /$ plant and12.15 t/ha) followed by Kohinoor-10 (71.02g/plant and $11.76 \mathrm{t} / \mathrm{ha})$ andMonsoon-10 (59.30 g/plant and $9.67 \mathrm{t} / \mathrm{ha})$. Kalloo et al (2005) reported that the highest fresh pod yield of the different varieties varied from $56-123.5 \mathrm{~g} /$ plant. Variation in the fresh yield in the different experiment might be due to growing condition and different variety used for the particular experimentation. Considering the interaction effect, on the basis of pooled value the highest fresh pod yield was recorded in KSP-110 (79.73 g/plant and $13.03 \mathrm{t} / \mathrm{ha}$ ) when grown with the application of conventional sources of nutrients followed by Kohinoor -10 (73.40 g/plant) when grown with the application of conventional sources of nutrients which was statistically at par with Kohinoor -10 (68.52 g/plant and $11.48 \mathrm{t} / \mathrm{ha})$ when grown with the application of organic sources of nutrients and significantly lowest fresh pod yield was recorded in Super Gold-10 (38.47 g/plant and $6.90 \mathrm{t} / \mathrm{ha})$ when grown under organic sources of nutrients.

\section{Pod quality parameters}

With respect to growing condition, shelling percentage did not vary significantly (Table3). However, higher shelling percentage $(45.74 \%)$ was recorded with the application of conventional sources of nutrients and lowest $(45.64 \%)$ in organic sources of nutrients. Among the different varieties, significantly highest shelling percentage was recorded in KSP-110 (47.17\%) followed by Azad P1 $(47.15 \%)$ and Kohinoor-10 (47.06\%) and lowest in Arkel (40.95\%). Kumari et al., (2008) reported that the high shelling percentage is an important criteria for economical production in pea. Chadha et al., (2013) observed that pod shelling percentage varied from 35.67 (DPP-54) to $66.17 \%$ (DPPMWR) in 2011-12 and 24.64 (FC-2) to
$57.08 \%$ (IC296678) in 2012-13. In the present experiment variation in the shelling percentage with respect to different variety was also noticed.

The perusal of data on protein content of garden pea as influenced by the varieties but not by the growing condition. With respect to growing condition, there was no significant effect on seed protein content. However, the maximum $(20.36 \%)$ protein content was recorded in organic sources of nutrients and minimum (19.89\%) protein content was recorded in conventional sources of nutrients. In this experiment, with respect to the different varieties of garden pea seed protein content varied from 18.50 to $21.59 \%$. Significantly the highest protein content was recorded in Monsoon-10 (21.59\%) followed by Azad P1 (20.77\%) and Arkel (20.58\%) and lowest in PSM-3 (18.50\%). Khichi et al., (2016) reported that variation in protein content among the different varieties of garden pea. They also reported that Palam Triloki exhibited the highest protein content of $23.06 \%$. Differences in protein content might be due to the genetic constitution of the genotypes. Regarding the interaction effects, highest protein content was recorded in Monsoon-10 (22.03\%) when grown with the application of organic sources of nutrients followed by Azad P1 (22.17\%) when grown with the application of organic sources of nutrients.

The observation recorded on ascorbic acid content $(\mathrm{mg} / 100 \mathrm{~g}$ fresh seed) of garden pea as influenced by the varieties. With respect to growing condition, on the basis pooled value the higher (25.84 $\mathrm{mg} / 100 \mathrm{~g}$ fresh seed) ascorbic acid content was recorded with the application of organic source of nutrients and lower $(23.94 \mathrm{mg} / 100 \mathrm{~g}$ fresh seed) ascorbic acid content with the application of conventional source of nutrients. But there was no significant difference in ascorbic acid content with respect to growing condition. 
Table.1 Plant height, nodules charcters and Pod length $(\mathrm{cm})$ of different varieties of garden pea under different nutrient sources

\begin{tabular}{|c|c|c|c|c|c|c|c|c|c|c|c|c|}
\hline \multirow[b]{2}{*}{ Particulars } & \multicolumn{3}{|c|}{ Plant height $(\mathrm{cm})$} & \multicolumn{3}{|c|}{ Number of nodules per plant } & \multicolumn{3}{|c|}{ Nodule dry weight $(\mathrm{mg} / 100 \mathrm{~g})$} & \multicolumn{3}{|c|}{ Pod length $(\mathrm{cm})$} \\
\hline & $2014-15$ & $2015-16$ & Pooled & $2014-15$ & $2015-16$ & Pooled & 2014-15 & $2015-16$ & Pooled & 2014-15 & $2015-16$ & Pooled \\
\hline \multicolumn{13}{|l|}{ Growing condition } \\
\hline Conventional nutrient source $\left(\mathrm{C}_{1}\right)$ & 43.79 & 47.42 & 45.61 & 12.10 & 12.88 & 12.49 & 150.85 & 171.61 & 161.23 & 8.18 & 8.09 & 8.14 \\
\hline Organic nutrient source $\left(\mathrm{C}_{2}\right)$ & 41.84 & 46.51 & 44.18 & 13.35 & 14.23 & 13.79 & 166.86 & 187.88 & 177.37 & 8.11 & 8.06 & 8.09 \\
\hline SEm \pm & 0.50 & 0.56 & 0.37 & 0.17 & 0.14 & 0.11 & 1.71 & 1.21 & 1.03 & 0.03 & 0.03 & 0.02 \\
\hline $\mathrm{CD}(\mathrm{P}=0.05)$ & 1.46 & 1.63 & 1.05 & 0.49 & 0.42 & 0.31 & 4.98 & 3.52 & 2.93 & N.S. & 0.08 & 0.06 \\
\hline \multicolumn{13}{|l|}{ Variety } \\
\hline $\mathrm{KSP}-110\left(\mathrm{~V}_{1}\right)$ & 40.65 & 49.95 & 45.30 & 11.83 & 12.90 & 12.37 & 142.83 & 160.50 & 152.16 & 8.27 & 8.43 & 8.35 \\
\hline Arkel $\left(\mathrm{V}_{2}\right)$ & 36.90 & 39.88 & 38.40 & 12.83 & 13.13 & 12.98 & 157.88 & 162.20 & 160.04 & 6.75 & 6.68 & 6.72 \\
\hline Super Gold-10 $\left(\mathrm{V}_{3}\right)$ & 40.77 & 44.77 & 42.77 & 14.20 & 14.60 & 14.40 & 165.55 & 184.62 & 175.08 & 8.43 & 8.32 & 8.38 \\
\hline PSM-3 $\left(V_{4}\right)$ & 40.13 & 43.43 & 41.78 & 10.63 & 11.40 & 11.02 & 137.44 & 156.45 & 146.95 & 8.10 & 8.47 & 8.28 \\
\hline Monsoon-10 $\left(\mathrm{V}_{5}\right)$ & 45.60 & 49.53 & 47.57 & 11.27 & 13.40 & 12.33 & 146.27 & 184.49 & 165.38 & 8.50 & 7.77 & 8.13 \\
\hline Azad P1 $\left(\mathrm{V}_{6}\right)$ & 48.83 & 51.87 & 50.35 & 16.00 & 17.03 & 16.52 & 210.00 & 237.83 & 223.92 & 8.45 & 8.58 & 8.52 \\
\hline Kohinoor-10 $\left(\mathrm{V}_{7}\right)$ & 46.83 & 49.33 & 48.08 & 12.33 & 12.40 & 12.37 & 150.99 & 172.11 & 161.56 & 8.53 & 8.28 & 8.41 \\
\hline SEm \pm & 0.94 & 1.05 & 0.69 & 0.32 & 0.27 & 0.11 & 3.21 & 2.27 & 1.03 & 0.06 & 0.05 & 0.02 \\
\hline $\mathrm{CD}(\mathrm{P}=0.05)$ & 2.74 & 3.05 & 1.96 & 0.93 & 0.79 & 0.31 & 9.32 & 6.59 & 2.93 & 0.17 & 0.15 & 0.10 \\
\hline \multicolumn{13}{|l|}{ Interaction $(C \times V)$} \\
\hline $\mathrm{C}_{1} \mathrm{~V}_{1}$ & 41.86 & 49.23 & 45.55 & 11.07 & 12.53 & 11.80 & 136.07 & 156.27 & 146.17 & 8.33 & 8.57 & 8.45 \\
\hline $\mathrm{C}_{1} \mathrm{~V}_{2}$ & 38.37 & 40.13 & 39.25 & 12.40 & 12.60 & 12.50 & 154.35 & 157.81 & 156.08 & 6.77 & 6.67 & 6.72 \\
\hline $\mathrm{C}_{1} \mathrm{~V}_{3}$ & 42.13 & 45.87 & 44.00 & 13.40 & 13.80 & 13.60 & 156.42 & 176.17 & 166.30 & 8.47 & 8.27 & 8.37 \\
\hline $\mathrm{C}_{1} \mathrm{~V}_{4}$ & 41.37 & 41.93 & 41.65 & 9.93 & 10.73 & 10.33 & 128.99 & 148.39 & 138.69 & 8.13 & 8.50 & 8.32 \\
\hline $\mathrm{C}_{1} \mathrm{~V}_{5}$ & 45.80 & 51.73 & 48.77 & 10.93 & 12.60 & 11.77 & 139.41 & 173.14 & 156.28 & 8.67 & 7.80 & 8.23 \\
\hline $\mathrm{C}_{1} \mathrm{~V}_{6}$ & 49.93 & 52.87 & 51.40 & 15.40 & 16.53 & 15.97 & 197.70 & 229.92 & 213.81 & 8.40 & 8.60 & 8.50 \\
\hline $\mathrm{C}_{1} \mathrm{~V}_{7}$ & 47.10 & 50.17 & 48.63 & 11.60 & 11.33 & 11.47 & 143.01 & 159.57 & 151.29 & 8.50 & 8.23 & 8.37 \\
\hline $\mathrm{C}_{2} \mathrm{~V}_{1}$ & 39.43 & 50.67 & 45.05 & 12.60 & 13.27 & 12.93 & 151.58 & 164.73 & 158.16 & 8.20 & 8.30 & 8.25 \\
\hline $\mathrm{C}_{2} \mathrm{~V}_{2}$ & 35.43 & 39.63 & 37.53 & 13.27 & 13.67 & 13.47 & 161.41 & 166.59 & 164.00 & 6.73 & 6.70 & 6.77 \\
\hline $\mathrm{C}_{2} \mathrm{~V}_{3}$ & 39.40 & 43.67 & 41.53 & 15.00 & 15.40 & 15.20 & 174.68 & 193.07 & 183.87 & 8.40 & 8.37 & 8.38 \\
\hline $\mathrm{C}_{2} \mathrm{~V}_{4}$ & 38.90 & 44.93 & 41.92 & 11.33 & 12.07 & 11.70 & 145.89 & 164.51 & 155.20 & 8.07 & 8.43 & 8.25 \\
\hline $\mathrm{C}_{2} \mathrm{~V}_{5}$ & 45.40 & 47.33 & 46.37 & 11.60 & 14.20 & 12.90 & 153.14 & 195.84 & 174.49 & 8.33 & 7.73 & 8.03 \\
\hline $\mathrm{C}_{2} \mathrm{~V}_{6}$ & 47.73 & 50.87 & 49.30 & 16.60 & 17.53 & 17.07 & 222.31 & 245.74 & 234.02 & 8.50 & 8.57 & 8.53 \\
\hline $\mathrm{C}_{2} \mathrm{~V}_{7}$ & 46.57 & 48.50 & 47.53 & 13.07 & 13.47 & 13.27 & 158.98 & 184.66 & 171.82 & 8.57 & 8.33 & 8.45 \\
\hline SEm \pm & 1.33 & 1.48 & 0.98 & 0.45 & 0.38 & 0.16 & 4.54 & 3.20 & 1.46 & 0.08 & 0.72 & 0.03 \\
\hline $\mathrm{CD}(\mathrm{P}=0.05)$ & 3.87 & 4.31 & 2.77 & 1.31 & 1.11 & 0.45 & 13.19 & 9.31 & 4.15 & N.S. & 0.21 & 0.08 \\
\hline
\end{tabular}


Table.2 Yield and yield characters of different varieties of garden pea under different nutrient sources

\begin{tabular}{|c|c|c|c|c|c|c|c|c|c|c|c|c|}
\hline \multirow[b]{2}{*}{ Particulars } & \multicolumn{3}{|c|}{ Number of pods per plant } & \multicolumn{3}{|c|}{ Number of seeds per pod } & \multicolumn{3}{|c|}{ Fresh pod yield (g/plant) } & \multicolumn{3}{|c|}{ Fresh pod yield (t/ha) } \\
\hline & $2014-15$ & $2015-16$ & Pooled & $2014-15$ & $2015-16$ & Pooled & $2014-15$ & $2015-16$ & Pooled & $2014-15$ & $2015-16$ & Pooled \\
\hline \multicolumn{13}{|l|}{ Growing condition } \\
\hline Conventional nutrient source $\left(\mathrm{C}_{1}\right)$ & 14.92 & 16.87 & 15.89 & 6.96 & 7.00 & 6.98 & 56.76 & 61.94 & 59.33 & 9.56 & 10.57 & 10.06 \\
\hline Organic nutrient source $\left(\mathrm{C}_{2}\right)$ & 13.89 & 15.78 & 14.83 & 6.84 & 6.77 & 6.80 & 51.86 & 56.31 & 54.09 & 8.86 & 9.48 & 9.17 \\
\hline SEm \pm & 0.23 & 0.35 & 0.20 & 0.03 & 0.02 & 0.02 & 0.50 & 0.69 & 0.42 & 0.09 & 0.11 & 0.07 \\
\hline $\mathrm{CD}(\mathrm{P}=0.05)$ & 0.66 & 1.00 & 0.58 & 0.09 & 0.07 & 0.06 & 1.47 & 2.00 & 1.19 & 0.26 & 0.32 & 0.20 \\
\hline \multicolumn{13}{|l|}{ Variety } \\
\hline KSP-110 $\left(\mathrm{V}_{1}\right)$ & 19.13 & 20.10 & 19.61 & 7.53 & 7.7 & 7.62 & 73.33 & 77.10 & 75.22 & 11.72 & 12.58 & 12.15 \\
\hline Arkel $\left(\mathrm{V}_{2}\right)$ & 12.82 & 13.95 & 13.38 & 5.32 & 5.37 & 5.34 & 43.30 & 48.50 & 45.90 & 7.43 & 7.72 & 7.58 \\
\hline Super Gold-10 $\left(\mathrm{V}_{3}\right)$ & 11.26 & 12.12 & 11.69 & 7.08 & 7.05 & 7.07 & 38.73 & 40.90 & 39.82 & 7.00 & 7.40 & 7.20 \\
\hline PSM-3 $\left(V_{4}\right)$ & 13.55 & 15.47 & 14.50 & 6.97 & 6.85 & 6.91 & 46.70 & 55.43 & 51.07 & 8.85 & 10.38 & 9.62 \\
\hline Monsoon-10 $\left(\mathrm{V}_{5}\right)$ & 15.10 & 16.57 & 15.83 & 7.25 & 6.93 & 7.09 & 58.00 & 60.60 & 59.30 & 9.57 & 9.77 & 9.67 \\
\hline Azad P1 $\left(\mathrm{V}_{6}\right)$ & 14.87 & 14.47 & 14.68 & 6.85 & 7.25 & 7.05 & 56.88 & 53.53 & 55.21 & 9.60 & 9.12 & 9.33 \\
\hline Kohinoor-10 $\left(\mathrm{V}_{7}\right)$ & 14.11 & 21.60 & 17.86 & 7.28 & 7.02 & 7.15 & 64.21 & 77.83 & 71.02 & 10.32 & 13.20 & 11.76 \\
\hline SEm \pm & 0.42 & 0.65 & 0.20 & 0.06 & 0.05 & 0.02 & 0.94 & 1.29 & 0.42 & 0.17 & 0.20 & 0.07 \\
\hline $\mathrm{CD}(\mathrm{P}=0.05)$ & 1.23 & 1.89 & 0.58 & 0.18 & 0.14 & 0.06 & 2.75 & 3.74 & 1.19 & 0.49 & 0.59 & 0.20 \\
\hline \multicolumn{13}{|l|}{ Interaction $(C \times V)$} \\
\hline $\mathrm{C}_{1} \mathrm{~V}_{1}$ & 19.81 & 21.05 & 20.43 & 7.67 & 7.90 & 7.78 & 77.67 & 81.80 & 79.73 & 12.37 & 13.70 & 13.03 \\
\hline $\mathrm{C}_{1} \mathrm{~V}_{2}$ & 13.51 & 14.64 & 14.07 & 5.30 & 5.47 & 5.38 & 44.67 & 50.60 & 47.63 & 7.77 & 8.17 & 7.97 \\
\hline $\mathrm{C}_{1} \mathrm{~V}_{3}$ & 11.55 & 12.31 & 11.93 & 7.20 & 7.30 & 7.25 & 39.87 & 42.47 & 41.17 & 7.30 & 7.70 & 7.50 \\
\hline $\mathrm{C}_{1} \mathrm{~V}_{4}$ & 14.11 & 16.40 & 15.26 & 6.93 & 7.00 & 6.97 & 49.07 & 59.27 & 54.17 & 9.23 & 10.80 & 10.02 \\
\hline $\mathrm{C}_{1} \mathrm{~V}_{5}$ & 15.35 & 17.51 & 16.43 & 7.33 & 6.97 & 7.15 & 60.47 & 63.60 & 62.03 & 9.83 & 10.47 & 10.15 \\
\hline $\mathrm{C}_{1} \mathrm{~V}_{6}$ & 15.15 & 14.83 & 15.00 & 6.90 & 7.30 & 7.10 & 59.30 & 55.33 & 57.32 & 9.97 & 9.53 & 9.75 \\
\hline $\mathrm{C}_{1} \mathrm{~V}_{7}$ & 14.98 & 21.35 & 18.16 & 7.37 & 7.03 & 7.20 & 66.27 & 80.53 & 73.40 & 10.47 & 13.60 & 12.03 \\
\hline $\mathrm{C}_{2} \mathrm{~V}_{1}$ & 18.45 & 19.15 & 18.80 & 7.40 & 7.5 & 7.45 & 67.23 & 72.40 & 69.82 & 11.07 & 11.47 & 11.27 \\
\hline $\mathrm{C}_{2} \mathrm{~V}_{2}$ & 12.12 & 13.26 & 12.69 & 5.33 & 5.27 & 5.30 & 41.93 & 46.40 & 44.17 & 7.10 & 7.27 & 7.18 \\
\hline $\mathrm{C}_{2} \mathrm{~V}_{3}$ & 10.97 & 11.93 & 11.44 & 6.97 & 6.8 & 6.88 & 37.60 & 39.33 & 38.47 & 6.70 & 7.10 & 6.90 \\
\hline $\mathrm{C}_{2} \mathrm{~V}_{4}$ & 12.97 & 14.53 & 13.75 & 7.00 & 6.70 & 6.85 & 44.33 & 51.60 & 47.97 & 8.47 & 9.97 & 9.22 \\
\hline $\mathrm{C}_{2} \mathrm{~V}_{5}$ & 14.84 & 15.62 & 15.23 & 7.17 & 6.90 & 7.03 & 55.53 & 57.60 & 56.57 & 9.30 & 9.07 & 9.18 \\
\hline $\mathrm{C}_{2} \mathrm{~V}_{6}$ & 14.63 & 14.10 & 14.36 & 6.80 & 7.20 & 7.00 & 54.47 & 51.73 & 53.10 & 9.23 & 8.70 & 8.97 \\
\hline $\mathrm{C}_{2} \mathrm{~V}_{7}$ & 13.24 & 21.85 & 17.55 & 7.20 & 7.00 & 7.10 & 61.90 & 75.13 & 68.52 & 10.17 & 12.80 & 11.48 \\
\hline SEm \pm & 0.60 & 0.92 & 0.29 & 0.09 & 0.07 & 0.03 & 1.33 & 1.82 & 0.60 & 0.24 & 0.29 & 0.10 \\
\hline $\mathrm{CD}(\mathrm{P}=0.05)$ & 1.74 & 2.67 & 0.82 & N.S. & 0.19 & 0.08 & 3.88 & 5.28 & 1.69 & 0.70 & 0.84 & 0.28 \\
\hline
\end{tabular}


Table.3 Quality characters of different varieties of garden pea under different nutrient sources.

\begin{tabular}{|c|c|c|c|c|c|c|c|c|c|c|c|c|}
\hline \multirow[b]{2}{*}{ Particulars } & \multicolumn{3}{|c|}{ Shelling percentage } & \multicolumn{3}{|c|}{ Protein content $(\%)$} & \multicolumn{3}{|c|}{ Beta carotene (IU/100g) } & \multicolumn{3}{|c|}{ Ascorbic acid (mg/100g) } \\
\hline & $2014-15$ & $2015-16$ & Pooled & $2014-15$ & $2015-16$ & Pooled & 2014-15 & 2015-16 & Pooled & $2014-15$ & $2015-16$ & Pooled \\
\hline \multicolumn{13}{|l|}{ Growing condition } \\
\hline Conventional nutrient source $\left(\mathrm{C}_{1}\right)$ & 45.92 & 45.57 & 45.74 & 19.58 & 20.20 & 19.89 & 597.17 & 616.83 & 607.00 & 23.92 & 23.97 & 23.94 \\
\hline Organic nutrient source $\left(\mathrm{C}_{2}\right)$ & 45.67 & 45.61 & 45.64 & 20.28 & 20.44 & 20.36 & 615.67 & 633.00 & 624.33 & 25.73 & 25.95 & 25.84 \\
\hline SEm \pm & 0.28 & 0.29 & 0.20 & 0.31 & 0.26 & 0.21 & 0.37 & 0.38 & 0.27 & 1.09 & 0.91 & 0.70 \\
\hline $\mathrm{CD}(\mathrm{P}=0.05)$ & N.S. & N.S. & N.S. & N.S. & N.S. & N.S. & 1.08 & N.S & 0.76 & N.S. & N.S. & N.S. \\
\hline \multicolumn{13}{|l|}{ Variety } \\
\hline $\mathrm{KSP}-110\left(\mathrm{~V}_{1}\right)$ & 46.40 & 47.93 & 47.17 & 20.03 & 20.78 & 20.41 & 624.50 & 682.00 & 653.25 & 27.98 & 29.55 & 28.77 \\
\hline Arkel $\left(\mathrm{V}_{2}\right)$ & 40.85 & 41.06 & 40.95 & 20.10 & 21.05 & 20.58 & 498.00 & 547.50 & 522.75 & 27.83 & 28.30 & 28.07 \\
\hline Super Gold-10 $\left(\mathrm{V}_{3}\right)$ & 46.46 & 46.00 & 46.23 & 18.90 & 19.37 & 19.13 & 717.00 & 750.00 & 733.50 & 22.42 & 21.65 & 22.03 \\
\hline PSM-3 $\left(V_{4}\right)$ & 46.94 & 45.95 & 46.45 & 18.60 & 18.40 & 18.50 & 625.00 & 647.50 & 636.25 & 25.02 & 24.37 & 24.69 \\
\hline Monsoon-10 $\left(\mathrm{V}_{5}\right)$ & 44.20 & 45.41 & 44.81 & 21.68 & 21.50 & 21.59 & 589.50 & 630.33 & 609.92 & 19.82 & 21.27 & 20.54 \\
\hline Azad P1 $\left(\mathrm{V}_{6}\right)$ & 47.68 & 46.66 & 47.17 & 20.43 & 21.10 & 20.77 & 618.00 & 539.17 & 578.58 & 28.17 & 26.25 & 27.21 \\
\hline Kohinoor-10 $\left(\mathrm{V}_{7}\right)$ & 48.03 & 46.09 & 47.06 & 19.75 & 20.03 & 19.89 & 573.00 & 578.00 & 575.50 & 22.55 & 23.32 & 22.93 \\
\hline SEm \pm & 0.52 & 0.55 & 0.20 & 0.57 & 0.49 & 0.21 & 0.69 & 0.71 & 0.27 & 2.03 & 1.71 & 0.70 \\
\hline $\mathrm{CD}(\mathrm{P}=0.05)$ & 1.51 & 1.59 & 0.58 & 1.66 & 1.42 & 0.58 & 2.01 & 1.00 & 0.76 & 5.92 & 4.97 & 1.98 \\
\hline \multicolumn{13}{|l|}{ Interaction $(C \times V)$} \\
\hline $\mathrm{C}_{1} \mathrm{~V}_{1}$ & 47.45 & 48.32 & 47.88 & 19.60 & 20.23 & 19.92 & 607.83 & 690.00 & 648.92 & 26.90 & 28.23 & 27.57 \\
\hline $\mathrm{C}_{1} \mathrm{~V}_{2}$ & 42.56 & 40.43 & 41.50 & 19.90 & 20.57 & 20.33 & 503.33 & 539.50 & 521.42 & 26.67 & 27.50 & 27.08 \\
\hline $\mathrm{C}_{1} \mathrm{~V}_{3}$ & 45.63 & 46.65 & 46.14 & 18.57 & 19.77 & 19.17 & 711.67 & 741.17 & 726.42 & 21.37 & 20.57 & 20.97 \\
\hline $\mathrm{C}_{1} \mathrm{~V}_{4}$ & 46.45 & 45.69 & 46.07 & 18.43 & 18.33 & 18.38 & 607.83 & 638.33 & 623.08 & 25.47 & 23.67 & 24.57 \\
\hline $\mathrm{C}_{1} \mathrm{~V}_{5}$ & 43.77 & 45.32 & 44.55 & 21.03 & 21.27 & 21.15 & 583.33 & 621.67 & 602.50 & 18.33 & 19.63 & 18.98 \\
\hline $\mathrm{C}_{1} \mathrm{~V}_{6}$ & 47.05 & 46.75 & 46.90 & 20.17 & 20.57 & 20.37 & 611.67 & 542.83 & 577.25 & 26.90 & 25.27 & 26.08 \\
\hline $\mathrm{C}_{1} \mathrm{~V}_{7}$ & 48.54 & 45.82 & 47.18 & 19.37 & 20.63 & 20.00 & 554.50 & 545.00 & 549.75 & 21.80 & 22.90 & 22.35 \\
\hline $\mathrm{C}_{2} \mathrm{~V}_{1}$ & 45.36 & 47.54 & 46.45 & 20.47 & 21.33 & 20.90 & 641.17 & 673.83 & 657.50 & 29.07 & 30.87 & 29.97 \\
\hline $\mathrm{C}_{2} \mathrm{~V}_{2}$ & 39.14 & 41.68 & 40.41 & 20.30 & 21.53 & 20.92 & 659.50 & 555.50 & 607.50 & 29.00 & 29.10 & 29.05 \\
\hline $\mathrm{C}_{2} \mathrm{~V}_{3}$ & 47.30 & 45.36 & 46.33 & 19.23 & 18.97 & 19.10 & 722.17 & 758.83 & 740.50 & 23.47 & 22.73 & 23.10 \\
\hline $\mathrm{C}_{2} \mathrm{~V}_{4}$ & 47.42 & 46.22 & 46.82 & 18.77 & 18.47 & 18.62 & 642.17 & 656.67 & 649.42 & 24.57 & 25.07 & 24.82 \\
\hline $\mathrm{C}_{2} \mathrm{~V}_{5}$ & 44.63 & 45.51 & 45.07 & 22.33 & 21.73 & 22.03 & 595.50 & 638.83 & 617.17 & 21.30 & 22.90 & 22.10 \\
\hline $\mathrm{C}_{2} \mathrm{~V}_{6}$ & 48.30 & 46.58 & 47.44 & 20.70 & 21.63 & 21.17 & 624.50 & 535.50 & 580.00 & 29.43 & 27.23 & 28.33 \\
\hline $\mathrm{C}_{2} \mathrm{~V}_{7}$ & 47.52 & 46.36 & 46.94 & 20.13 & 19.43 & 19.78 & 591.67 & 611.17 & 601.42 & 23.30 & 23.73 & 23.52 \\
\hline SEm \pm & 0.73 & 0.78 & 0.29 & 0.81 & 0.69 & 0.29 & 0.98 & 1.00 & 0.38 & 2.88 & 2.42 & 0.99 \\
\hline $\mathrm{CD}(\mathrm{P}=0.05)$ & 2.13 & 2.25 & 0.82 & N.S. & N.S. & N.S. & N.S & N.S & N.S & N.S. & N.S. & N.S. \\
\hline
\end{tabular}


Table.4 Benefit cost ratio of garden pea under different growing condition.

\begin{tabular}{|c|c|c|c|c|}
\hline $\begin{array}{l}\text { Varieties under different } \\
\text { sources of nutrients }\end{array}$ & $\begin{array}{c}\text { Cost of } \\
\text { cultivation } \\
\text { (Rs./ha) }\end{array}$ & $\begin{array}{c}\text { Gross return } \\
\text { (Rs./ha) }\end{array}$ & $\begin{array}{c}\text { Net return } \\
\text { (Rs./ha) }\end{array}$ & B:C \\
\hline $\mathrm{C}_{1} \mathrm{~V}_{1}$ & 84601 & 260600 & 175999 & 2.08 \\
\hline $\mathrm{C}_{1} \mathrm{~V}_{2}$ & 84601 & 159400 & 74799 & 0.88 \\
\hline $\mathrm{C}_{1} \mathrm{~V}_{3}$ & 84601 & 150000 & 65399 & 0.77 \\
\hline $\mathrm{C}_{1} \mathrm{~V}_{4}$ & 84601 & 200400 & 115799 & 1.37 \\
\hline $\mathrm{C}_{1} \mathrm{~V}_{5}$ & 84601 & 203000 & 118399 & 1.40 \\
\hline $\mathrm{C}_{1} \mathrm{~V}_{6}$ & 84601 & 224250 & 139649 & 1.65 \\
\hline $\mathrm{C}_{1} \mathrm{~V}_{7}$ & 85851 & 240600 & 154749 & 1.80 \\
\hline $\mathrm{C}_{2} \mathrm{~V}_{1}$ & 93130 & 270480 & 177350 & 1.90 \\
\hline $\mathrm{C}_{2} \mathrm{~V}_{2}$ & 93130 & 172320 & 79190 & 0.85 \\
\hline $\mathrm{C}_{2} \mathrm{~V}_{3}$ & 93130 & 165600 & 72470 & 0.78 \\
\hline $\mathrm{C}_{2} \mathrm{~V}_{4}$ & 93130 & 221280 & 128150 & 1.38 \\
\hline $\mathrm{C}_{2} \mathrm{~V}_{5}$ & 93130 & 220320 & 127190 & 1.37 \\
\hline $\mathrm{C}_{2} \mathrm{~V}_{6}$ & 93130 & 215280 & 122150 & 1.31 \\
\hline $\mathrm{C}_{2} \mathrm{~V}_{7}$ & 93130 & 275520 & 182390 & 1.96 \\
\hline & & & & \\
\hline & & 9 & & \\
\hline & & 950 & \\
\hline
\end{tabular}


Among the different varieties, significantly highest ascorbic acid content was recorded in KSP-110 (28.77mg/100g fresh seed) followed by Arkel (28.07mg/100g fresh seed) and Azad P1 $(27.21 \mathrm{mg} / 100 \mathrm{~g}$ fresh seed) and lowest ascorbic acid content was recorded in Monsoon-10 (20.54mg/100g fresh seed). Considering the interaction effect, highest ascorbic acid content was recorded in KSP$110(29.97 \mathrm{mg} / 100 \mathrm{~g}$ fresh seed) when grown with the application of organic sources of nutrients followed by Arkel $(29.05 \mathrm{mg} / 100 \mathrm{~g}$ fresh seed) when grown with the application of organic sources of nutrients followed by Azad P1 (28.33mg/100g fresh seed) when grown with the application of organic sources of nutrients and significantly lowest ascorbic acid content was recorded in Monsoon-10 $(18.98 \mathrm{mg} / 100 \mathrm{~g}$ fresh seed)when grown with the application of conventional nutrient sources.

With respect to growing condition, on the basis of pooled value the higher (624.33 IU/100g) Beta carotene content was recorded in organic sources of nutrients and lower (607 IU/100g) Beta carotene content was recorded in conventional sources of nutrients. In this experiment, with respect to the different varieties of garden pea Beta carotene content varied from 733.50 to $522.75 \mathrm{IU} / 100 \mathrm{~g}$ fresh seed. Significantly the highest Beta carotene content was recorded in Super Gold-10 (733.50 IU/100g fresh seed) followed by KSP-110 (653.25 IU/100g fresh seed) and PSM-3 (636.25 IU/100g fresh seed) and lowest Beta carotene content was recorded in Arkel (522.75 IU/100g fresh seed).

\section{Benefit cost ratio}

Maximum benefit cost ratio (2.08) was recorded in the varietyKSP-110 under conventional growing condition followed by Kohinoor -10 (1.96) with organic sources of nutrients and KSP-110 (1.90) under organic sources of nutrients. The lowest (0.77) benefit cost ratio was recorded in Super Gold-10 when grown with the application of conventional sources of nutrients. So, the cultivation of garden pea variety KSP-110 under conventional growing condition followed by Kohinoor -10 with organic sources of nutrients and KSP-110 under organic sources of nutrients were beneficial under the terai zone of west Bengal.

In conclusion considering the fresh pod yield and benefit: cost ratio, the garden pea variety KSP-110 may be selected for growing under conventional nutrient sources whereas, Kohinoor -10 may be selected for growing with organic sources of nutrients under the terai zone of West Bengal.

\section{References}

Amjad, M. and Anjum, M. A. (2002). Performance of nine pea cultivars under Faisalabad conditions. Pakistan Journal of Agricultural Sciences, 39(1). 16-19

Anonymous, (2013-14). Ministry of Agriculture, govt. of India, 85 Institutional area, sector 18, Gurgaon, India.

Chadha, S., Rameshwar, Saini, J. P. and Sharma, S. (2013). Performance of different varieties of pea (Pisum sativum L.) under organic farming conditions in Mid Himalayas. International Journal of Agriculture and Food Science Technology, 4(7): 733-738.

Gomez, K. A. and Gomez, A. A. (1984). Statistical Procedures in Agricultural Research, Chichester 2nd edition, New York. pp. 680.

Kalloo, G., Rai, M., Singh, J., Verma, A., Kumar, R., Rai, G. K., Vishwanath. (2005). Morphological and biochemical variability in vegetable 
pea (Pisum sativum L.). Vegetable Science, 32(1): 19-23.

Khichi, P., Chandan, P. M., Chauhan, J., Srinivas, J., Bhagat, M. (2016). Varietal evaluation of garden pea under semi-arid conditions of Vidharba region. International Journal of Farm Science, 6(1): 20-24.

Kumari, A., Kumar, M., Kohli, U. K. (2008). Genetic parameters and character association in garden pea (Pisum sativum L.) cultivars. Vegetable Science, 35(2): 160-164.

Makasheva, R. K. (1983). The pea. Oxonian Press Pvt Ltd New Delhi India. Pp. 78-107.

Mishra, N. (2014). Growth and yield response of pea (Pisum sativum L.) to Integrated Nutrient Management- A Review. Journal of Plant and Pest Science, 1(2): 87-95.

Muehlbauer, E. J. and McPhee, K. E. (1997). Peas, The physiology of vegetable crops. $C A B$ International Wallingford: 429-459.
Negi, S., Singh, R. V., Dwivedi, O. K. (2006). Effect of Biofertilizers, nutrient sources and lime on growth and yield of garden pea, Legume research 29(4): 282-285.

Orr, C. H., Leifert, C., Cummings, S. P., Cooper, J. M. (2012). Impacts of organic and conventional crop management on diversity and activity of free-living nitrogen fixing bacteria and total bacteria are subsidiary to temporal effects. PLOS ONE 7(12): 113.

Singh, R. B., Singh, D., Singh, D. N. (1980). Response of field pea to population density and phosphorus levels. Indian Journal Plant Physiology, 23(2): 185191.

Wood, R., Lenzen, M., Dey, C., Lundie, S. (2006). A comparative study of some environmental impacts of conventional and organic farming in Australia, Agricultural Systems 89(23): 324-348.

\section{How to cite this article:}

Vijay Kumar, S., Suchand Datta and Shibnath Basfore. 2018. Performance of Garden Pea (Pisum sativum var hortense L.) Varieties under Conventional and Organic Nutrient Sources under Sub-Himalayan Foot Hills of West Bengal Int.J.Curr.Microbiol.App.Sci. 7(07): 32313241. doi: https://doi.org/10.20546/ijcmas.2018.707.377 